\title{
Morphometric analysis of the masseter muscle post unilateral lower molar exodonty: experimental study
}

\author{
BENIGNO, M. I. M. ${ }^{1 *}$, AMSTALDEN, E. M. I. ${ }^{2}$, LIBERTI, E. A. ${ }^{3}$, \\ LEAL, N. M. S. ${ }^{1}$, RODRIGUES, K. E. L. ${ }^{1}$ and MOTA, V. B. ${ }^{1}$ \\ ${ }^{1}$ Department of Morphology, Health Sciences Center, Universidade Federal do Piaui - UFPI, Campus Minister \\ Petronio Portela, Ininga, CEP 64049-550, Teresina, PI, Brazil \\ ${ }^{2}$ Department of Pathology, Faculty of Medical Sciences, Universidade Estadual de Campinas - UNICAMP, Rua \\ Tessália Vieira de Camargo,126, Cidade Universitária Zeferino Vaz, CEP 13083-887, Campinas, SP, Brazil \\ ${ }^{3}$ Department of Anatomy, Institute of Biomedical Sciences, Universidade de São Paulo - USP, \\ Rua Irineu Prestes, 2415, Cidade Universitária, CEP 05508-900, Butantã, São Paulo, SP, Brazil \\ *E-mail: ivone@ufpi.edu.br
}

\begin{abstract}
Introduction: To check the morphological changes of the masseter muscle after surgical extraction of inferior molar teeth. Methods: 24 Wistar rats had samples of their masseter muscles analysed in the Optical Microscope $(\mathrm{OM})$. The rats were randomly divided into three groups as follows: GI-15, GII-30, GII-60 days after surgical extraction of inferior molar teeth. Each group had 5 experimental and 3 normal control rats for OM observation. The OM allowed the morphometric study of the masseter muscle. The morphometric study was based on the measurement of the fiber's area by AXION-VISION software. ANOVA test was applied for data analysis. Results: No alteration was detected in all morphometric analysis of the masseter muscle. Conclusion: The masseter muscle adapts to the occlusal modification caused by the extraction of the molar teeth during the analysed periods.
\end{abstract}

Keywords: masseter muscle, muscle fiber, light microscopy.

\section{Introduction}

The mastication is strongly associated to the temporomandibular joint (TMJ) and to masticator muscles. The majority of temporomandibular dysfunction (TMD) has occlusal alterations as predisposing or coadjutant factor, which has been identified as responsible for the impairment of masticator muscles. The jaw elevator muscles keep the mandibular physiological postural position against the gravity action, emphasizing the Masseter, Medial Pterigoid and Temporal muscles. According to Dawson (2008), the occlusal alterations in human dentition can cause painful symptomatology, due to the accumulation of toxins resulting from the concentration of products from the cellular metabolism. Cao et al. (2010) investigated the Masseter muscle histological alterations, concluded that in the occlusal interferences, the muscular pain experimentally induced is associated to peripheral sensitization of nociceptive neurons, instead of muscular lesion and inflammation. The MPT and Masseter muscles act synergistically to elevate jaw and contribute to its protrusion. There is a synchrony between masticator muscles and TMJ in masticatory activity, as related by Iyomasa, Issa, Oliveira et al. (2008) and Iyomasa, Issa, Sosthines et al. (2009), who investigated the ultrastructural and histological effects over the MTP muscle of gerbils in occlusal alterations induced by unilateral extraction. These studies showed, through micrograph data, that unilateral teeth extraction was able to induce modifications in PTM muscle fibres and capillaries. Many factors can lead to occlusal disharmony such as: tooth loss (MIEHE, FANGHÄNEL, KUBEIN-MEESENBURG et al., 1999; BENIGNO, AZEREDO, LEMOS et al., 2001; BAZAN, ISSA, WATANABE et al., 2008), premature contact in dental occlusion (BAKKE, 1993); use of orthodontic braces and dentures (CVETKO, KAREN and ERZEN, 2012) wear and abrasion of occlusal surface of teeth (BANI, BANI and BERGAMINI, 1999; SANTIWONG, MURAMOTO, SOMA et al., 2002). Some studies discuss the effects of occlusal disharmony in human stomatognathic system (BANI, BANI and BERGAMINI, 1999; BENIGNO, AZEREDO, LEMOS et al., 2001; KORFAGE, WANG, LIE et al., 2000). Benigno, Azeredo, Lemos et al. (2001), studied the alterations in the bilaminar zone of TMJ, in young adults and elders, and verified alterations of collagen and elastic fibers in the different age groups, in which they observed morphological alterations in the collagen fibers of elders. Animal models has been stimulated due to the limitations of experiments in humans and to the anatomic and functional similarity to the human masticatory muscles. Studies have been carried out with different animal models and under various aspects about the macroscopic, microscopic and ultrastructural findings of masticatory muscles. The pathophysiological mechanisms to muscular adaptation remain poorly comprehended, and more studies related to pathological and morphofunctional alterations are necessary.

\section{Materials and Methods}

\subsection{Sample characterization and division of groups of animals}

Were used twenty-four rats from Wistar lineage, one-month aged, weighing on average $220 \mathrm{~g}$, male, proceeding from the Central Vivarium of Federal University of Piauí. Initially, 
the animals were kept in a proper environment, distributed in acrylic cages of $30 \times 19 \times 16 \mathrm{~cm}$ length, containing one animal each, which were daily cleaned. All the animals were previously submitted to clinical evaluation to guarantee the state of health. The diet was normally kept ration and water ad libitum-based. The animals were divided into three groups according to the distinct evolutional period analyzed: 15 days (GI); 30 days (GII) and 60 days (GIII), after extraction of mandibular molars, each experimental group with three animals and the control groups with one animal. The control groups were not submitted to any pharmacological or surgical protocol. The Ethics Committee in Animal Experimentation - CEEA/UFPI, approved under the number $072 / 11$, all the procedures of this study.

\subsection{Surgical procedure}

The animals in experimental groups were submitted to left mandibular molars extraction (Figure 1) to induce the dysfunction of TMJ. For this procedure, the animals were pre-medicated with opioid ( $6 \mathrm{mg}$ tramadol $/ \mathrm{kg}$ ) by deep intramuscular injection to ensure analgesia. After ten minutes they were submitted to general anaesthesia dissociative kind, where was used the anaesthetic association ketamine (Dopalen) $50 \mathrm{mg} / \mathrm{k}$, xylazine (Rompum) $0.5 \mathrm{mg} / \mathrm{kg}$ in the same syringe, injected via intramuscular. Once concluded the surgical procedures (extractions), the animals were submitted to preventive antibiotic therapy (Penicillin / streptomycin - 40,000UI/kg) by deep intramuscular injection and anti-inflammatory (Flunixin meglumine $1.0 \mathrm{mg} / \mathrm{kg}$ ) every twenty-four hours for a period of three days. To the realization of extractions, was used an adapted Weingart 120E pliers (Figure 2). The post operatory was daily evaluated and the animals were kept under technical care from vivarium, all the experimental period long.

At the end of each period: 15 days (Group I); 30 days (Group II) and 60 days (Group III) was carried out the euthanasia of animals from experimental group with the correspondent control group. The euthanasia of the animals used, was performed by administering an overdose of anesthetic (10 times the dose used for conventional anesthesia), causing the animal to death due to cardiac arrest. Bilateral masseter muscles of each animal were removed whole and extended in brown paper surface for facilitating proper cutting plan.

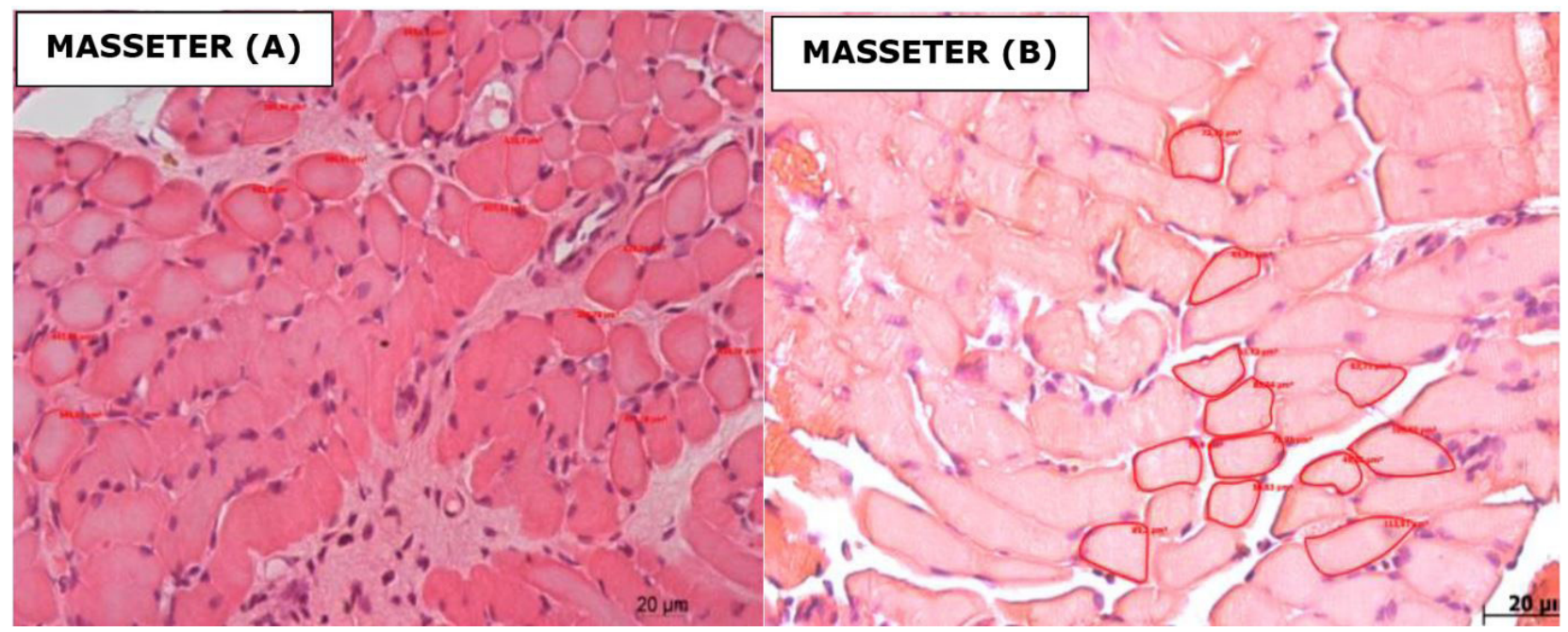

Figure 1. Constituency of fibers to measure area in $\mu \mathrm{m}^{2}$, Masseter muscle left (A) and right (B), GI (15 days).

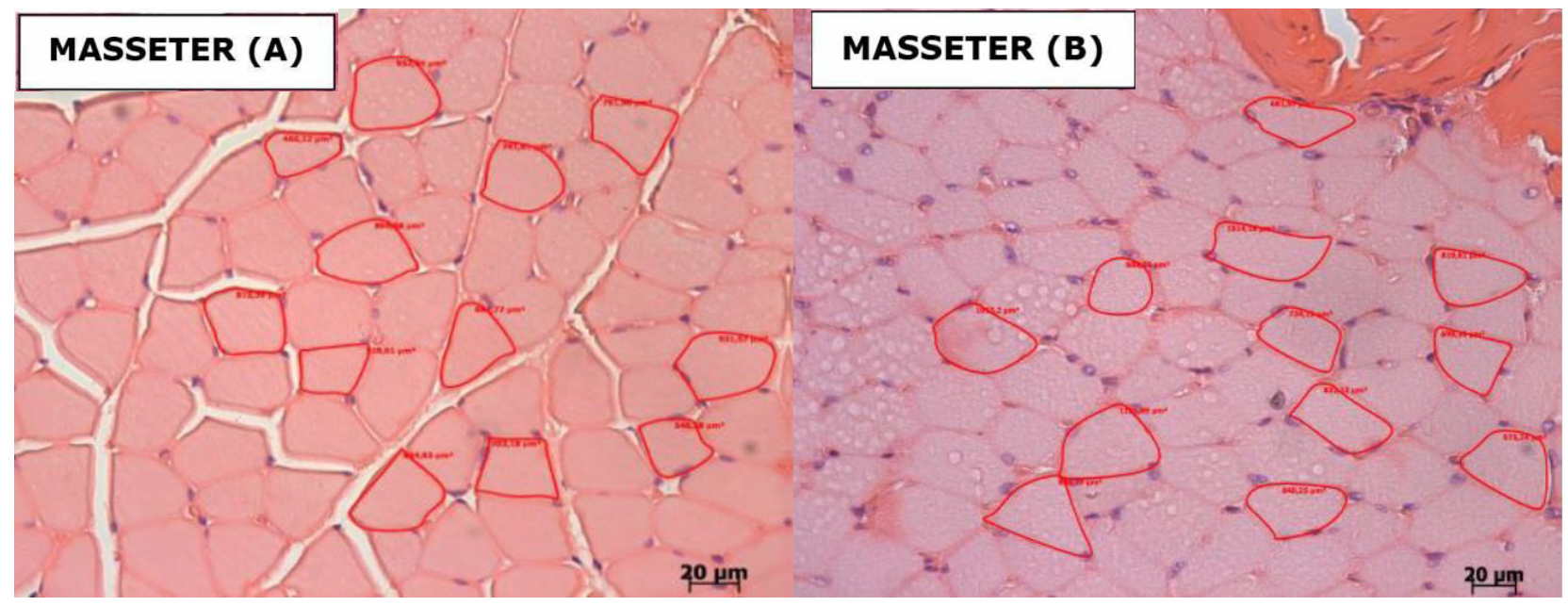

Figure 2. Constituency of fibers to measure area in $\mu \mathrm{m}^{2}$, Masseter muscle left (A) and right (B), GII Group (30 days). 
The deepest part of the masseter was obtained a fragment in cross section, about $0,3 \mathrm{~cm}$ thick.

\subsubsection{Technique for Light Microscopy (ML)}

The material obtained from each animal was fixed in $10 \%$ buffered formalin; maintained for 24 hours, and subsequently, processed through a routine technique for embedding in paraffin. Each block corresponding to each of the right and left masseter muscles in the experimental group and the control group left Muscles, slides were prepared containing five cross-sections, semi -serial, with $5 \mu \mathrm{m}$ thick.

\subsubsection{Morphometry - quantitative analysis}

The study was based on morphometric analysis of the extent of the area of the fiber, using transverse sections stained using hematoxylin and eosin (HE). In microscopic 10× magnification, the best field containing fibers with their well-defined limits were selected (Figure 2A). This field was subjected to a $40 \times$ magnification and photographed in a light microscope (Leica DMRB, Germany) coupled to a digital program. From the obtained image, twelve fibers were selected to carry out the measure of area. This measurement was taken and be limited to fiber and its value was calculated through a software program AXION-vision (Figure 2B). A total of sixty measurements per plate were obtained in the experimental group, i.e., 240 steps per animal a total of 1200 measurements per group. Already, in the control group, a total of one hundred steps per slide was conducted, 200 steps per animal and 600 steps per group.

\subsection{Statistical analysis}

The statistical analysis was applied on data obtained as the morphometric measurements area of the muscle fibers of the masseter muscle, using ANOVA. There was the comparison between the experimental and control groups; between measures of areas of the muscles of the right and left sides of the experimental groups and left side of the control group.

\section{Results}

The morphometric analysis of the masseter muscle showed no difference when comparing the rats subjected to the experiment and the control group, as regards the global average area of these fibers, as both ipsilateral contralateral to the extraction in the period analyzed $(\mathrm{p}=0.520)$. similarities were observed when comparing sides to each other $(\mathrm{p}=0.200)$ (Graphic 1$)$, and when the questions rated interaction between groups and side ( $\mathrm{p}=0.926$, Figure 2$)$, the area of muscle fibers of left and right sides have the same behavior as a function of time after extraction ( 15 days, 30 days and 60 days). There was also no interaction between the mean area of the muscle fibers of the experimental and control groups, both on the left as on the right, the different evolutionary periods (Table 1 and Figure 3 ).

When evaluating the distribution area of the fibers, it is noted that for the GI group (right and left), there is a higher concentration of fibers ranges between 400 and $700 \mu \mathrm{m}^{2}$ (Graphic 2) and the control group increased concentration is in the range of 400 to $600 \mu \mathrm{m}^{2}$, for all stages of evolution (Graphic 2-4). For the GII (right and left) the concentration of fibers was between the ranges of 400 and $600 \mu^{2}$ (Graphic 3 ). The GIII showed higher concentration in the range of 400 to $800 \mu^{2}$ to the left and right sides (Graphic 4).

\section{Discussion}

Jaw movements are directly related to the jaw muscle. Any disharmony of the stomatognathic system may have passed this musculature. Studies discuss the effects of occlusal disharmony in the human stomatognathic system

Table 1. Average values in $\mu \mathrm{m},{ }^{2}$ as the morphometric analysis of Masseter muscle area in experimental animals and control, in the different evolutionary periods.

\begin{tabular}{|c|c|c|c|c|c|c|c|c|c|}
\hline \multirow{2}{*}{$\begin{array}{c}\text { MASSETER } \\
\text { MUSCLE }\end{array}$} & \multicolumn{3}{|c|}{ Group I (GI) 15 days } & \multicolumn{3}{|c|}{ Group II (GII)30 days } & \multicolumn{3}{|c|}{ Group III(GIII) 60 days } \\
\hline & E-r & E-1 & C- 1 & E-r & E-1 & C-1 & E-r & E-1 & C-1 \\
\hline & $701.2 \pm 240.1$ & $582.5 \pm 225.7$ & $512.3 \pm 198.0$ & $684.6 \pm 288.8$ & 694.8254 .0 & $672.6 \pm 298.6$ & $673.4 \pm 250.0$ & $773.9 \pm 311.7$ & $687.0 \pm 230.9$ \\
\hline
\end{tabular}

Comparison between the right and left sides $(\mathrm{p}=0.200)$ and also right and left sides in different groups (evolutionary periods) GI = 15; $\mathrm{GII}=30$ and GIII = 60 days. And E-r = experimental muscle right; E- $\mathrm{l}=$ experimental muscle left; C-l = control left.

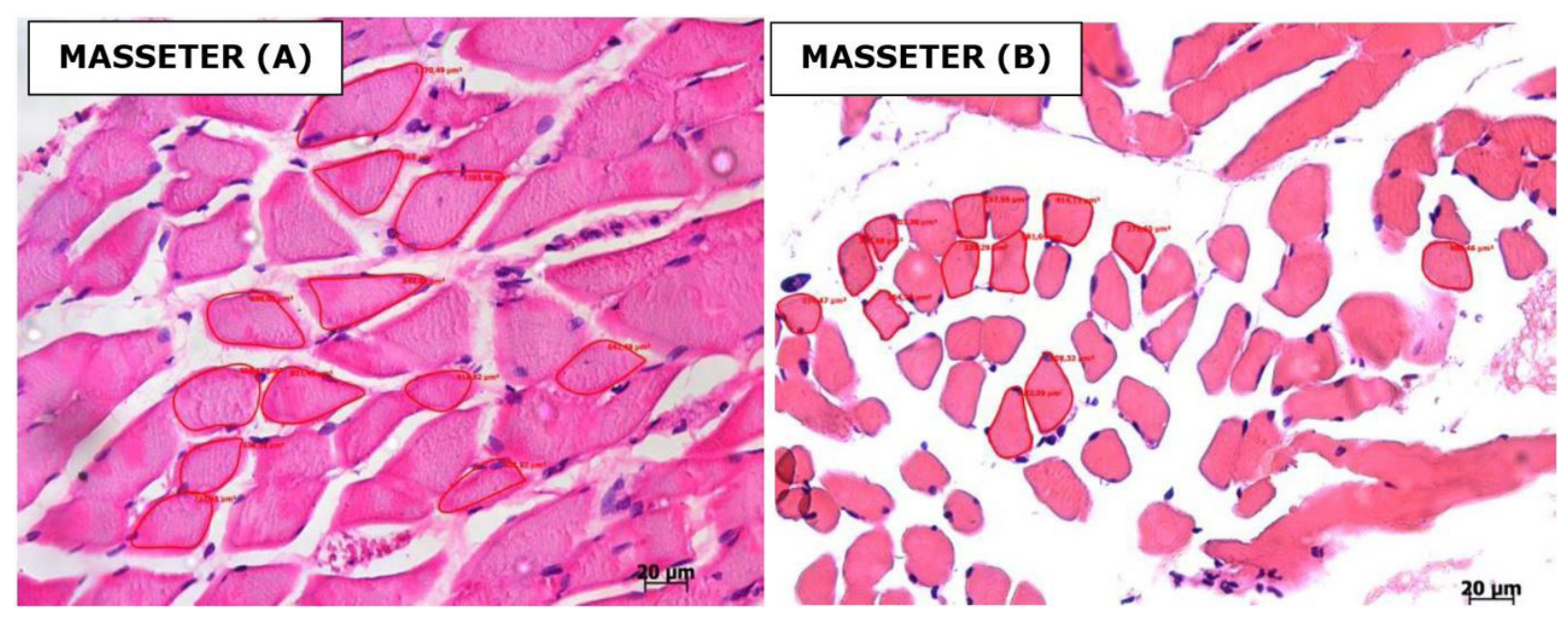

Figure 3. Constituency of fibers to measure area in $\mu \mathrm{m}^{2}$, Masseter muscle left (A) and right (B), GIII (60 days). 


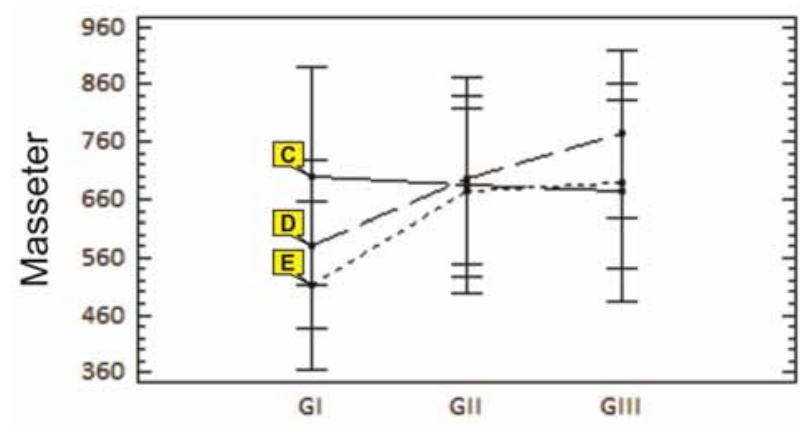

Graphic 1. Results observed in area measurement $\mu \mathrm{m}^{2}$, between the experimental group and control left and right sides, in different evolutionary periods $(\mathrm{p}=0.671) . \mathrm{E}=\mathrm{left} ; \mathrm{D}=$ right and $\mathrm{C}=$ control.

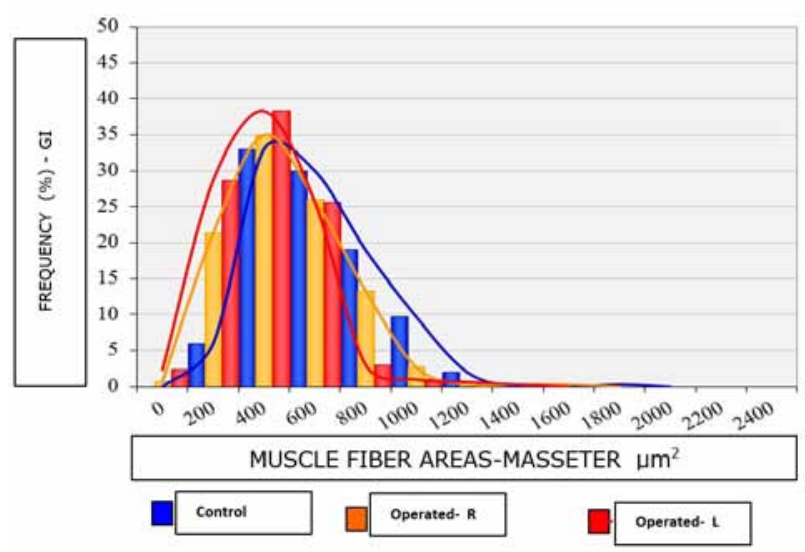

Graphic 2. Average values for the area $\left(\mu \mathrm{m}^{2}\right)$ and their distribution curves of the Masseter muscle fibers of the GI Group (right and left sides) and control group (ICG), corresponding to the evolutionary period of 15 days.

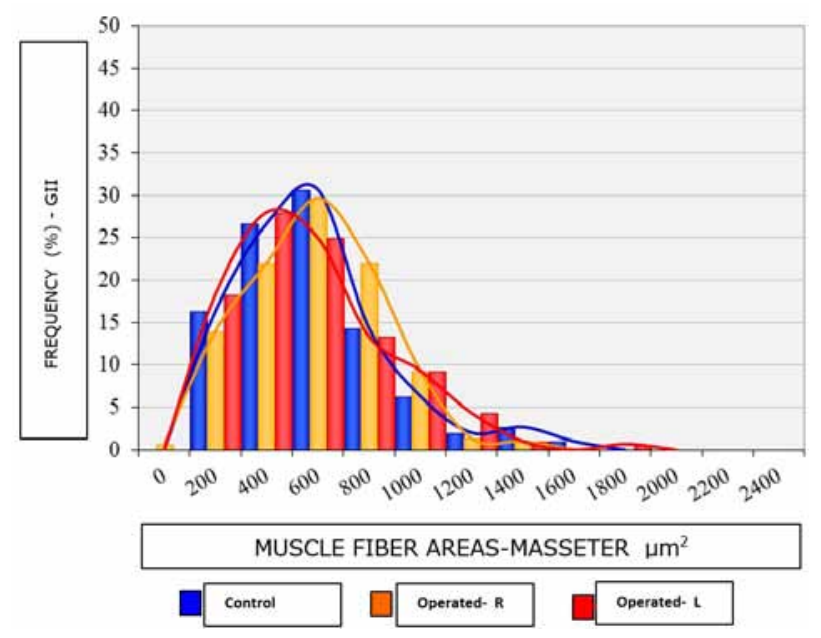

Graphic 3. Average values for the area $\left(\mu \mathrm{m}^{2}\right)$ and their distribution curves of the Masseter muscle fibers of the IGI Group (right and left sides) and control group (GCII), corresponding to the evolutionary period of 30 days.

(BENIGNO, AZEREDO, LEMOS et al., 2001; SCIOTE, HORTON, ROWLERSON et al., 2012; KORFAGE, WANG, LIE et al., 2000). The bilaminar area of human ATM, one

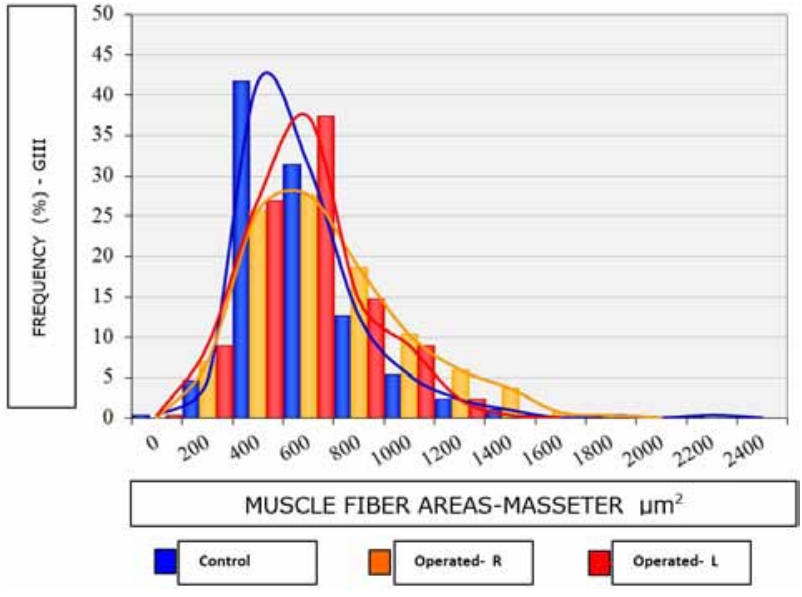

Graphic 4. Average values for the area $\left(\mu^{2}\right)$ and their distribution curves of the Masseter muscle fibers of the GIII group.

of the components of the stomatognathic system, in studies presented morphological changes when qualitatively compare the structure in young individuals (toothed) and elderly (edentulous) (BENIGNO, AZEREDO, LEMOS et al., 2001).

Animal models have been stimulated as a result of the limitations of these experiments in humans (CVETKO, KAREN and ERZEN, 2012; IYOMASA, ISSA, OLIVEIRA et al., 2008; EASTON and CARLSON, 1990; NISHIDE, BABA, HORI et al., 2001). In this study, the choice of Wistar rat as an experimental model was based on the similarity of anatomy, architectural location and arrangement of the masseter muscle, the human, as described SATOH and IWAKU, (2004).

Morphological analysis has contributed little in change detection of skeletal muscle fibers (CVETKO, KAREN and ERZEN, 2012; IYOMASA, ISSA, SOSTHINES et al., 2009; NISHIDE, BABA, HORI et al., 2001). Due to the need for a study method more objective and accurate, so morphometry has been increasingly used in the evaluation of skeletal muscle fibers (MIEHE, FANGHÄNEL, KUBEIN-MEESENBURG et al., 1999; BAZAN, ISSA, WATANABE et al., 2008; BANI, BANI, BERGAMINI et al., 1999; IYOMASA, ISSA, OLIVEIRA et al., 2008; CAMARGO, VANDERLEI, CAMARGO et al., 2005; ANDREO, OLIVEIRA, NAVARRO et al., 2002).

Among the studies that used morphometry to the measure of skeletal muscle fiber area, a study resembles much with this method stating that there is an increased area of the rat soleus muscle fiber after exercise (CAMARGO, VANDERLEI, CAMARGO et al., 2005).

The morphometry was used in a survey developed by Andreo, Oliveira, Navarro et al. (2002); the quantification and measurement of the area of the types of fast and slow oxidative muscle fibers, muscle: masseter, temporal and digastric monkeys. The result was verified that the fast fibers have larger area and are more frequent in all regions studied. In addition, no difference in frequency or area of each fiber type was detected, whereas the anterior and posterior regions of the masseter and temporalis muscles.

In our study, the morphometric analysis of the masseter muscle showed no difference between the experimental and control animals, the global analysis comprising the three stages of evolution. There was no change in the area of muscle 
fibers in animals subjected to extraction, on both sides of the masseter muscle.

Vreeke, Langerbach, Korfage et al. (2011), found a decrease in area of slow fibers of the masseter muscle, with a reduction in masticatory load. The evaluation of the masseter through the fiber area measurement showed a temporary muscle atrophy and found an increase of the area of the rat soleus muscle fibers after exercise (SEIRYU, DAIMARUYA, IIKUBO et al., 2012). Miehe, Fanghänel, Kubein-Meesenburg et al. (1999), evaluating the weight and the type of fiber from the jaw, after molar extraction, in Wistar rats, found weight reduction and increase of type II fibers.

In our study, no differences were detected when comparing the global average measure of the masseter muscle area, right and left sides with each other, as well as to the question interaction between sides and groups in different stages of evolution. These data indicate that the fibers of these jaw muscles undergo similar changes, post unilateral molar extraction. Seiryu, Daimaruya, Iikubo et al. (2012), found temporary atrophy of the masseter muscle, while adapted to the new position of the mandible. Miehe, Fanghänel, Kubein-Meesenburg et al. (1999), they found the adaptation and return of the fibers to its original standard, the weight and the type of fiber from the jaw, both the macroscopic level and microscopic, at the end of the experiment, showing adaptability of them. This adaptive capacity is also checked in Soleus muscle fibers of mice that suffered hypertrophy after exercise (CAMARGO, VANDERLEI, CAMARGO et al., 2005).

Acknowledgements: The Department of Pathology, University of Campinas (Unicamp), the Applied Functional Anatomy Laboratory to the Clinic and Surgery (LAFACC), Department of Anatomy, University of São Paulo (USP) and the Department of Morphology of the Federal University of Piauí (UFPI), the scientific and technical support which enabled the development of the work.

\section{References}

ANDREO, JC., OLIVEIRA, JA., NAVARRO, JAC., ROQUE, DD., ROQUE, JS. and BUCHAIN, RL. Histoenzymology and morphometry of the masticatory muscles of tufted capuchin monkey(Cebus apela Linnaeus,1758). Okajimas Folia Anatomica Japonica, 2002, vol. 79, n. 1, p. 33-42. http://dx.doi.org/10.2535/ ofaj.79.33. PMid:12199536.

BAKKE, M. Mandibular elevator muscles: physiology, action, and effect of dental occlusion. Scandinavian Journal of Dental Research, 1993, vol. 101, n. 5, p. 314-331. PMid:8248735.

BANI, D., BANI, T. and BERGAMINI, M. Morphologic and Biochemical changes of the masseter muscles induced by occlusal wear: studies in a rat model. Journal of Dental Research, 1999, vol. 78, n. 11, p. 1735-1744. http://dx.doi.org/10.1177/00220345 990780111101. PMid:10576170.

BAZAN, E., ISSA, JPM., WATANABE, IS., LACERDA, CAM., DEL BEL, EA. and IYOMASA, MM. Ultrastructural and biochemical changes of the medial pterygoid muscle induced by unilateral exodontia. Micron (Oxford, England), 2008, vol. 39, n. 5, p. 536-543. http:// dx.doi.org/10.1016/j.micron.2007.07.006. PMid:17826114.

BENIGNO, MIM., AZEREDO, RA., LEMOS, JLR., KÖNIG JÚNIOR, B. and LIBERTI, EA. The structure of the bilaminar zone in the human temporomandibular joint: a light and scanning electron microscopy study in young and elderly subjects. Journal of Oral Rehabilitation, 2001, vol. 28, n. 2, p. 113-119. http:// dx.doi.org/10.1046/j.1365-2842.2001.00683.x. PMid:11298258.
CAMARGO, JCSF., VANDERLEI, LCM., CAMARGO, RCT., OLIVEIRA, DAR., OLIVEIRA JÚNIOR, AS., DAL PAI, V. and BELANGERO, WD. Análise histológica, histoquímica e morfométrica do músculo sóleo de ratos submetidos a treinamento físico em esteira rolante. Arq. Ciências Saúde., 2005, vol. 12, n. 3, p. 196-199.

CAO, Y., LI, K., FU, KY. and XIE, QF. Experimental occlusal interference induces the expression of protein gene products and substance P in masseter muscles of rats. Beijing Da Xue Xue Bao. Yi Xue Ban, 2010, vol. 42, n. 1, p. 50-55. PMid:20140043.

CVETKO, E., KAREN, P. and ERZEN, I. Wearing of complete dentures reduces slow fibre and enhances hybrid fibre fraction in masseter muscle. Journal of Oral Rehabilitation, 2012, vol. 39, n. 8 , p. 608-614. http://dx.doi.org/10.1111/j.1365-2842.2012.02294.x. PMid:22489880.

DAWSON, PE. Oclusão Funcional: da ATM ao desenho do sorriso. São Paulo: Santos; 2008. 650 p.

EASTON, WJ. and CARLSON, D. Adaptation of the lateral pterygoid and superficial masseter muscles to mandibular protrusion in the rat. American Journal of Orthodontics and Dentofacial Orthopedics, 1990, vol. 97, n. 2, p. 149-158. http://dx.doi.org/10.1016/08895406(90)70088-T. PMid:2301301.

IYOMASA, MM., ISSA, JPM., OLIVEIRA, F., STUANI, MBS., OLIVEIRA, AM. and WATANABE, IS. Morphological and histological effects on the medial pterygoid muscle after unilateral exodontia in gerbils. Micron (Oxford, England), 2008, vol. 39, n. 7, p. 785-790. http://dx.doi.org/10.1016/j.micron.2008.01.019. PMid:18343131.

IYOMASA, MM., ISSA, JPM., SOSTHINES, MCK., OLVEIRA, AM., STUANI, MBS., MOTOYAMA, AA. and WATANABE, IS. Ultrastructural characteristics of the gerbil pterygoid medial muscle after experimental occlusal alteration. Micron (Oxford, England), 2009, vol. 40, n. 2, p. 206-211. http://dx.doi.org/10.1016/j. micron.2008.09.002. PMid:18977663.

KORFAGE, JAM., WANG, J., LIE, S. and LANGENBACH, GEJ. Intermuscular and intramuscular differences in myosin heavy chain composition of the human masticatory muscles. Journal of the Neurological Sciences, 2000, vol. 178, n. 2, p. 95-106. http:// dx.doi.org/10.1016/S0022-510X(00)00372-5. PMid:11018701.

MIEHE, B., FANGHÄNEL, J., KUBEIN-MEESENBURG, D., NÄGERL, H. and SCHWESTKA-POLLY, R. Masticatory musculature under altered occlusal relationships: a model study with experimental animals. Annals of Anatomy, 1999, vol. 181, n. 1, p. 37-40. http:// dx.doi.org/10.1016/S0940-9602(99)80084-3. PMid:10081556.

NISHIDE, N., BABA, S., HORI, N. and NISHIKAWA, H. Histological study of rat masseter muscle following experimental occlusal alteration. Journal of Oral Rehabilitation, 2001, vol. 28, n. 3, p. 294-298. PMid:11350580.

SANTIWONG, P., MURAMOTO, T., SOMA, K. and TAKANO, Y. Growth-associated protein- 43 immunohistochemical and ultrastructural changes in jaw muscle spindles of the rat following loss of occlusion. Archives of Oral Biology, 2002, vol. 47, n. 3, p. 227-237. http:// dx.doi.org/10.1016/S0003-9969(01)00101-7. PMid:11839359.

SATOH, K. and IWAKU, F. Internal architeture, origin-insertion site, and mass of jaw muscles in old world hamsters. Journal of Morphology, 2004, vol. 260, n. 1, p. 101-116. http://dx.doi. org/10.1002/jmor.10198. PMid:15052600.

SCIOTE, JJ., HORTON, MJ., ROWLERSON, AM., FERRI, J., CLOSE, JM. and RAOUL, G. Human masseter muscle fiber type properties, skeletal malocclusions, and muscle growth factor expression. Journal of Oral and Maxillofacial Surgery, 2012, vol. 70, n. 2, p. 440-448. http://dx.doi.org/10.1016/j.joms.2011.04.007. PMid:21821327. 
SEIRYU, M., DAIMARUYA, T., IIKUBO, M., WATANABE, K. and TAKANO-YAKAMOTO, T. Decreases of occlusal vertical dimension induce changes in masticatory muscle fiber composition. Orthodontic Waves, 2012, vol. 71, n. 4, p. 123-128. http://dx.doi. org/10.1016/j.odw.2012.05.003.

VREEKE, M., LANGERBACH, GEJ., KORFAGE, JAM., ZENTNER, A. and GRÜNHEID, T. The masticatory system under varying functional load. Part 1: structural adaptation of rabbit jaw muscles to reduced. European Journal of Orthodontics, 2011, vol. 33, n. 4, p. 359-364. http://dx.doi.org/10.1093/ejo/cjq083. PMid:20923937.

Received August 3, 2015 Accepted July 8, 2016 